Haaga-Helia

ammattikorkeakoulu

\title{
HUOM! TÄMÄ ON RINNAKKAISTALLENNE.
}

Käytä viittauksessa alkuperäistä lähdettä:

Vuori, J. (2015). Excellent prospects for beautiful minds: marketing international education. International Journal of Educational Management, 29(5), 582-595.

http://dx.doi.org/10.1108/lJEM-10-2013-0156

PLEASE NOTE! THIS IS PARALLEL PUBLISHED VERSION OF THE ORIGINAL ARTICLE.

To cite this article:

Vuori, J. (2015). Excellent prospects for beautiful minds: marketing international education. International Journal of Educational Management, 29(5), 582-595.

http://dx.doi.org/10.1108/lJEM-10-2013-0156 


\section{Excellent prospects for beautiful minds: marketing international education}

\section{Introduction}

Marketing concepts and theories are increasingly used by higher education institutions (HEIs) in the global education market (Hayes, 2009; Hemsley-Brown and Oplatka, 2006; Hemsley-Brown, 2011). Some writers have no difficulty applying marketing theories into higher education by referring to education as either a product or service, describing university students as customers and using tools associated with emotional and brand marketing (Anctil, 2008; Durkin et al., 2012; Hayes, 2009; Ivy, 2008; Moogan, 2011; Mulnix et al., 2011; Ross et al., 2013; Vauterin et al., 2011; Wright, 2012). For these authors, marketing is a means to ensure long-term student satisfaction which is achieved through a wide range of activities that are tailored on student needs. Marketing decisions are not only generated based on marketing communications but on the offered product, price, place, people, physical facilities and processes (Ivy, 2008). The role of marketing communication is to provide information which helps the informed customer to make the right decision.

There are, however, critics who warn of the consequences of treating students as customers. Critics argue that higher education marketing blurs the intellectual function of university by providing the university with a role as a service provider. In addition, critics suggest that marketing messages alter the perception of academic work and warn of the consequences of marketing campaigns that address prospective students as customers. Much criticism has also been raised towards marketing in its effort to emphasise degrees and gained skills as end results instead of concentrating on advancing learning and research. Moreover, marketing is blamed for obscuring the role of the academy as a place for intellectual pursuit in its tendency to emphasise the "student experience". (Acevedo, 2011; Arambewela, 2010; Askehave, 2007; Gibbs, 2008; Grebennikov and Shah, 2013; Molesworth et al., 2009; Naidoo and Jamieson, 2005; Newman and Jahdi, 2009; Ramachandran, 2010; Stachowski, 2011; Svensson and Wood, 2007; Symes, 1996; Williams, 2013.)

Arambewela (2010) argues that student consumerism is the dominant discourse of higher education globalisation. International education offers HEIs not only new funding 
opportunities but also means to ensure qualified future labour force for the needs of the knowledge economy. The vocational agenda in its emphasis on employability is thus at the core of globalisation discussion. Moreover, according to Arambewela (2010) the promotion of student experience is an outcome of higher education marketisation and commodification. The student experience is a concept used to describe constantly changing student perceptions of both academic and non-academic life. When trying to get a deeper insight in the higher education globalisation the examination of marketing communications of HEIs is relevant because it is through these messages the HEIs try to convince prospective students to "choose us" and differentiate themselves from international competitors.

Finnish HEIs attempt to get their share of the international education market, too. The internationalisation strategy for Finnish higher education aims to increase the number of international degree students (Finnish Ministry of Education, 2009). International students are necessary because the population demographics indicate a growing trend of retirement and resulting shortage of future talent in the labour market. Moreover, in a country where tuition-free higher education has traditionally been one of the core higher education values, the Ministry of Education and Culture has launched a trial that allows master's programmes to charge tuition from students from non-EU/EEA countries. These simultaneous objectives are arguably contradictory (Cai and Kivistö, 2013). However, the objectives reflect the global higher education discourse in an enlightening way. Many HEIs are attempting to attract more applicants simultaneously to their free and tuition fee programmes. As a consequence, prospective students struggle to locate accurate information on whether Finnish higher education will remain free. Much responsibility is given to the marketers of international programmes, who, if participating in the tuition fee experiment, are required to be specific in their marketing regarding the tuition fees and grant opportunities (Pyykkö et al., 2012).

Finnish higher education consists of two sectors of almost equal size: research universities and universities of applied sciences (UASs). Although both sectors provide 
bachelor's and master's degrees, their missions differ. Research universities are oriented towards scientific research and are in charge of doctoral education in the country whereas research and development activities within UASs represent a minor activity compared to teaching. Instead of scientific research UASs conduct applied research which tries to boost regional innovation and economy and have relevance to professional education and practice. According to a recent international evaluation the undergraduate students' involvement in research and development activities is a "striking feature" of teachingresearch nexus at Finnish UASs (Maassen et al., 2012). Both higher education sectors have successfully attracted non-Finnish students and created international degree programmes resulting in growing student numbers in the last fifteen years. In spring 2012, there were 12,999 international students enrolled in 399 international programmes of which 257 programmes were offered by Finnish universities and 142 by Finnish UASs (Välimaa et al., 2013). The outcomes of the tuition fee trial have been less successful. In 2011, there were 110 tuition paying degree students, of which 98 covered their studies entirely or partially with an institutional grant. In 2012 of the 215 students coming from outside EU/EEA - area to tuition programmes and only 11 students financed their studies on their own. Finnish HEIs participating in the tuition experiment acknowledge the necessity to improve their marketing competence and admit that they presently use similar marketing strategies for both free and tuition fee programmes (Pyykkö et al., 2012; Pyykkö et al., 2013).

Students have also criticised the marketing efforts of Finnish UASs (Union of Students in Finnish Universities of Applied Sciences, 2009; 2011). Although not specifically referring to international student recruitment, students accuse UASs of misleading marketing practices and creating false images in student recruitment campaigns. Students even claim that the names of degree programmes have been modified to be more attractive to potential applicants (Union of Students ..., 2009). Students demand HEIs to be truthful in their marketing and request that instead of portraying false images HEIs should provide prospective students with facts such as application and graduation statistics. Moreover, students insist that applicants should have access to course descriptions in order to verify the claims of marketing campaigns.

The accusations of UAS student union is supported by a survey according to which $21 \%$ of UAS students were dissatisfied with the truthfulness of their institution's marketing (Lavikainen, 2010). According to this survey, students' disappointment was a result of a 
mismatch between the expectations that had been created in the application period and the reality the students faced once admitted. The mismatch related to the quality of teaching, actual course selection opportunities, the experienced level of internationalisation, perceived opportunities to collaborate with the representatives of the industry and the lack of either practical or theoretical orientation in studies.

Although HEIs representatives and their students have criticised marketing practices, Finnish higher education marketing is largely unstudied. This paper examines the admissions websites of international business and technology programmes and is the first comprehensive study of the marketing communication practises of international higher education programmes in Finland. The research question is: how do the programmes articulate market differentiation on their websites? The analysis is further guided through examination of the two major themes related to the discussion of marketisation of global higher education: how do the international programmes promote the vocational agenda and student experience in their online marketing? Moreover, as the programme sample has been collected within the timeframe of Finnish tuition-fee experiment it offers an opportunity to examine whether the marketing messages of free and tuition-collecting programmes differ. This study contributes to the study of global international market mechanisms and research on marketing communication practised by higher education institutions.

\section{Marketing international higher education}

The goal of market differentiation is to communicate to the target audience how the offered product or service suits customer requirements better than any other available option. The communication should be so convincing that it leads to action. When promoting higher education programmes, marketers must emphasise the differentiating characteristics or qualities that are more appealing to potential applicants than those offered by other programmes. Moreover, higher education marketers must assure the applicants that they are making the correct decision. In higher education, however, differences are often small and difficult to observe. Therefore, the marketer of higher education programme is advised to accentuate the present subtle differences that are not apparent to the audience (Anctil, 2008; Hayes, 2009; van Rooij and Lemp, 2010). 
The knowledge of the customer needs, should be the basis for all marketing activities and a starting point for institutional market differentiation strategies. Previous research has shown that applicants decide to study abroad based on both push and pull factors (Wilkins et al., 2012). Push factors refer to the opportunities and conditions in the students' home countries, whereas the pull factors refer to the quality of education and reputation of the target country or institution and opportunities for language improvement and cultural experiences. In addition, personal and human factors, attitudes towards religion and safety and the influence of reference groups and social networks have been observed to contribute to study abroad decisions. Due to the general lack of studies on motivation to study in non-English speaking countries (Wilkings et al, 2012) and the nonexistence of such research in Finland particularly (Cai and Kivistö, 2013), the marketing differentiation efforts of Finnish HEIs are hardly based on true detection of the needs and requirements of prospective international students.

International student marketing uses multiple promotional tools and channels. In addition to institutional websites and published marketing material, Finnish HEIs, for example, advertise through educational portals, attend educational fairs and arrange entrance examinations outside of Europe (Välimaa et al., 2013). However, as “online mirrors of institutional environment" (Cohen et al., 2013: 6), institutional websites are critical for convincing potential students to "choose us". Previous studies on the use of websites for internationalisation purposes have been performed with different approaches in different contexts. These studies have accounted for both the actions of applicants (Gomes and Murphy, 2003; Hemsley-Brown, 2012) and institutions (Bishop, 2013; Cohen et al., 2013; Ooi et al., 2010). The international degree programme descriptions of four Finnish HEI websites have been examined by Saarinen and Nikula (2013) in their investigation of the role of language in the internationalisation policy of Finnish higher education. However, none of these studies has focused on how the websites communicate the marketing differentiation strategies of international programmes.

\section{Data and methods}

The data were collected in March 2013 from the webpages of Finnish HEIs that recruited students in English language business or technology programmes (Appendix 1). These study fields were chosen because in spring 2012, they covered 50 percent of the 
international degree programmes of Finnish research universities and 74 percent of the international programmes offered by UASs (Välimaa et al. 2013). These programmes are also important in the global marketplace because they are among those that have been most lucrative for new universities when becoming involved in the international student market (Hemsley-Brown, 2011). The examination included both bachelor's and master's degree programmes. The sample covered the main university admissions webpage and subsequent pages leading to the descriptions of the degree programmes. The analysis was conducted based on the text but excluded pictures and videos. PDF-attachments or student and alumni stories were excluded. If several technology or business programmes were advertised by an HEI, the initially introduced programme was sampled, except if it was a joint or multidisciplinary programme, in which case the subsequent programme was selected. Two other exceptions were generated, thus disregarding the first introduced programme in favour of the second. These programmes - an architectural and a management assistant programme - were considered to represent special niches among the mainstream business and technology programmes.

This strategy yielded a total of 68 international degree programmes from 23 Finnish UASs and 10 Finnish universities. The sample covered admissions texts of 42 business and 26 technology programmes. Thirty-eight programmes were bachelor's and 30 were master's programmes. One-half $(n=15)$ of the master's programmes charged tuition fees from non-EU/EEA citizens from 5,000 - 10,500 euros per academic year.

The method of the analysis was qualitative content analysis. Instead of quantifying the themes, the aim of the examination was to richly describe the themes introduced in the texts. Both deductive and inductive coding was used to construct the theme categories. The texts were initially repeatedly read and then coded into wide categories of marketing differentiation topics proposed by Anctil (2008). The author suggests that HEIs could articulate marketing differentiation based on their 1) academic reputation, 2) social life and campus amenities and 3) the halo effect on the athletic programme. This coding cycle confirmed that these themes, which refer to North American student recruitment practice, are not applicable to the Finnish context because the data contained few references to campus amenities and only one reference to an athletic programme. Thus, the last category was omitted. The categories of academic reputation and social life were then coded into smaller subgroups as illustrated in Table 1 and are further described in the following. Quotations from the original texts are included to illustrate how the themes 
were introduced in the admissions texts.

\section{Table 1 here}

\section{Academic reputation}

Anctil (2008) advises HEIs to provide evidence of their academic reputation by emphasising a favourable ranking status and connect to the reputation with either academic postgraduate activities or occupational outcomes. The academic reputation building themes observed on the Finnish programme websites were 1) formal programme recognitions and achievements of the teaching staff, 2) labour market relevance and graduates' career prospects and 3) teaching and research orientations of the programmes. In the data, only a small minority of the programmes communicated academic reputation by referring to ranking status, accreditation or prizes and nominations received. Whereas most of these texts provided the reader with specific details, there were also texts that caused the reader to question the accreditation or ranking that was referred to. Similarly, there was a range of expressions from specific to vague when the achievements of the teaching staff were introduced. Whereas one institution (Åbo Akademi University) provided specific details of an award obtained by a professor, the professors at the Hanken School of Economics were described as "well-known", and at the University of Vaasa, the recipients had "received several international research awards". In other cases, the quality of the staff was advertised by referring to their business or international background in general terms, including "Our lecturers have extensive business experience and international careers" (Tampere UAS).

Instead of referring to scholarly reputation, it was more common to emphasise the reputation that programmes have among businesses. The co-operation with the labour market was heavily promoted by indicating its role in ensuring curriculum relevancy, providing placements and projects, enabling practice-oriented teaching and increasing graduate employment opportunities.

Metropolia and its teachers have the best company and work life networks. (Metropolia UAS) 
Our education receives acclaim from employers because our teaching meets the demands of modern working life well. (University of Vaasa)

Our programme is designed in cooperation with business representatives to enhance your future career prospects. (Lappeenranta University of Technology)

The degree programmes strongly accentuated the future employment prospects of their graduates. Typically, these prospects were communicated by a paragraph describing the labour needs in the field and linking these needs to the curriculum.

Modern business development often requires close interaction with both customers and suppliers, and therefore industrial marketing and global sourcing strategies are the cornerstones of our programme. In addition to theoretical understanding, the programme emphasises the practical competencies that young graduates need when managing and developing business processes in international markets. (Tampere University of Technology)

With the aim to specify career prospects, it was typical, particularly to the bachelor programmes, to provide examples of the titles that their graduates would obtain after graduation. Some programmes were confident with their promises for the future: "Graduates are highly competitive knowledge workers in the global labour markets" (Haaga-Helia UAS), "you will be able to establish and lead business activities in any Nordic country" (Arcada UAS) and the "degree guarantees work opportunities that are related to business management, marketing, export and import activities as well as product and service development" (Karelia UAS). Programmes that did not want to provide such large promises favoured sentences using "may" or "can" and included lists of typical or representative titles or occupations of their former graduates.

Through studies in Engineering Physics and Mathematics you can become an internationally recognized scholar or expert, start up your own company or become a business consultant. (Aalto University)

You can be a designer, a developer, a tester, a supervisor, an operator, a marketing or sales engineer, a project engineer, a government or local agency official or involved in professional association work. (Satakunta UAS) 
More than one-half of the programmes referred to teaching methods on their websites, thus portraying a variety of pedagogic orientations. In addition to promoting company projects, HEIs advertised the "latest learning technologies" (Turku UAS) and "innovative" (Lappeenranta University of Technology) or "interactive and collaborative" (Saimaa UAS) teaching methods and provided the reader with examples such as simulation games, role playing, case-studies and problem-based learning. In particular, master's programmes emphasised that studying can be combined with full-time work, "Study while you are building your career" (Hämeenlinna UAS)", and advertised the convenience of weekend lectures, e-learning or study options that can occur "at times and in order chosen by the students" (Laurea UAS). In addition, elective courses were promoted for students to customise the curriculum to their individual needs. This customisation was promoted using messages such as "tailor your education to your particular needs and interests" (Arcada UAS) and promises of "flexibility to pursue your own interests" (Mikkeli UAS).

Whereas both sectors emphasised the teaching-research nexus through collaboration with working life, research universities also provided more general statements of the nexus promoting that "education and research are closely intertwined" (University of Turku) or that "a deep scientific basis of the education is ensured" (Lappeenranta University of Technology). These institutions also used "scientific" or "academic" research terminology to differentiate their research from UASs that, according to their mission, conduct applied research.

The importance of connections with the labour market was not only highly promoted to ensure academic reputation and practise oriented teaching methods, but the physical proximity to companies was also mentioned as an advantage when the HEI location was promoted.

\section{Social life}

After studying potential US college applicants, Capraro et al. (2004) concluded that the perceived social life is at least as important as the perceived quality of education. Therefore, the researchers recommend HEIs to promote personal and social interactions on campus so applicants could feel welcome. In the admissions texts of Finnish 
international programmes, two subcategories of the social life theme were distinguished: 1) personal guidance and individual advice and 2) atmosphere.

Whereas Finnish universities offer more international programmes than Finnish UAS, the number of students in the university programmes is smaller (Välimaa et al., 2013).

However, programmes from both sectors advertised opportunities of personal guidance and the availability of the staff for their students.

The departments are small and former students say that it was easy to feel at home at the university. The contact between teachers and students is good. (Åbo Akademi University)

To facilitate adaptation to the new learning environment and processes, we will have a consultation with every student about his or her orientation, on the basis of which we make a personal curriculum for each one. (Saimaa UAS).

The student community was described as "tight-knit" (Aalto University), "real" (Centria UAS), and able to provide personal networks for a lifetime (Hämeenlinna UAS, Hanken School of Economics), whereas the environment was described as "relaxed and informal" (Tampere University of Technology) or "intimate" (Hanken School of Education).

However, the student community or atmosphere was frequently described as "international". Internationalisation was explained by providing references to a multicultural student body and teaching staff and emphasising opportunities to study abroad through international networks. Some programmes differentiated themselves as more international than others by promoting themselves as "highly", "genuinely" or "truly" international.

Our multicultural teaching staff, daily involvement in classroom activities with students from all over the world, our active contact with business life and our global network add to the international flavour of the programme. (Jyväskylä UAS)

Studying in multicultural teams gives you an excellent opportunity to learn about various cultures and to create valuable relationships and international networks. 
(Saimaa UAS)

\section{Conclusions}

This study investigated marketing communication practises of international higher education programmes in Finland by analysing how business and technology degree programmes on both bachelor and master levels promoted the vocational agenda and student experiences in their websites when trying to articulate market differentiation. In addition, the marketing messages of master-level programmes which collect tuition-fees were compared with those who do not. The findings indicated that the marketing messages contained plenty of references to the vocational agenda while the references to student experience concentrated on the academic affairs. Differences between tuitioncollecting and free programmes were not found.

The results of this study show that when Finnish HEI international programmes want to attract prospective students to their business and technology programmes, the "beautiful minds", as addressed by Lappeenranta University of Technology, they strongly emphasise the labour market relevance of the degree. The Finnish HEIs thus echo the vocational agenda and accentuate the value of a degree as contribution to the economy. Higher education is marketed as a means to an end, not as an end itself. A degree programme is promoted as a technical endeavour which provides the most efficient way to acquire the skills demanded by the global labour market. The labour market relevance overshadows the value of higher education as pursuit of critical and independent thought. (Arambewela, 2010; Gibbs, 2008; Newman and Jahdi, 2009; Molesworth et al., 2009; Williams, 2013). In their student recruitment, programmes at both research universities and UASs emphasise the skills to be gained, the value of the degree in the labour market and present collaboration opportunities with companies. The labour market relevance was promoted on the websites by advertising graduates' employability skills, emphasising the employers' role in curriculum design, providing the names of companies in the cooperation network, referring to projects and placements that will be provided through these networks, underscoring practical teaching methods and emphasising the teachingresearch nexus in collaboration with industrial networks. The strong market orientation was also evident when the programmes promoted their location by referring to the city's active business life or business network opportunities on campus. 
The strong consumeristic orientation was further emphasised by programmes in both sectors referring to education as an "investment in the future" (Williams, 2013), emphasising opportunities to tailor studies according to individual needs and by promising "excellent" career prospects. The career prospects were promoted through lists of jobs the students are able to get after graduation. The international nature of the programme was also promoted as an opportunity to gain a further differentiating competitive advantage in global market. Finnish HEIs can promise lucrative futures and offer lists of dream jobs because there are no regulations that would force HEIs to provide evidence of graduate employment, as the HEIs in Britain, for example, are required to do (Williams, 2013).

However, the websites of Finnish international programmes cannot be criticised for overemphasising the non-academic aspects of student experience. The references to atmosphere and relationships in the community were given either in connection with learning or accentuating the future benefits of the networks that students havebuilt during their studies. The HEIs were thus regarded as places where one obtains employability skills and references to the non-academic side of student experience was almost nonexistent. In this respect the results differ from those of Askehave (2007), Jacob et al. (2013) and Symes (1996) who in their studies showed that HEIs were promoted as tourist destinations, country clubs or theme parks. Moreover, the websites portrayed a wide variety of examples of the HEIs searching for market differentiation through pedagogic orientation, the use of student-centred teaching methods, involving students in research and development activities, dedication to personal study guidance and commitment to create a working atmosphere where students and staff support individual study efforts.

This study provided further proof that Finnish HEIs' observations use similar marketing techniques for free and tuition fee programmes (Pyykkö et al., 2012; 2013). While a previous study has shown that Finnish higher education students have contradictory views on whether they want to be seen as customers (Vuori, 2013), the findings of this study indicated that the main approach for communicating with potential applicants of international business and technology programmes was addressing prospective students as customers (Acevedo, 2011; Naidoo and Jamieson, 2005; Molesworth, Nixon and Scullion, 2009; Ramachandran, 2010; Svensson and Wood, 2007; Vuori, 2013; Williams, 
2013) and used similar rhetoric emphasising what "we" can offer "you" to make "your" individual goals come true.

\section{Discussion}

With an orientation towards qualitative research, this study aimed at transferability by establishing connections between its results and the results or argumentations presented in previous discussions of higher education marketing. Moreover, this study was systematic in its attempt to create dependability by showing consistency in the manner it was reported and confirmability by attempting to connect the data so it could be understood by the readers (Eriksson and Kovalainen, 2008).

This study concentrated on business and technology programmes because these are the major fields in which Finnish HEIs have established international programmes. These fields are also market-oriented by the nature of their disciplines. Thus, a further study should analyse whether the emphasis on instrumental educational values would manifest itself in a similar manner in other study fields. Whereas this study was based on text only a further investigation of photographs and student narratives, would provide further insight into marketing differentiation efforts and possibly open new insights into the marketing of non-academic parts of student experience. This research area would also benefit from comparative international studies taking also different legislative restrictions into account.

Marketing should not be of interest of the marketing departments of HEIs only, but a concern of everyone having a stake at higher education. Marketing messages used for recruiting students have an effect on students' perceptions of their relationship with their university (Svensson and Wood, 2007; Ramachandran, 2010; Stachowski, 2011). For that reason, academics, maybe higher education researchers in particular, should not only be aware of the possible clashes between the messages sent by their institution's marketing department with their own values but could also initiate either general or institutional-level discussions on the special nature of higher education marketing.

Considering the results of this study, it not difficult to share the critique of UAS students when they argue that higher education marketing in Finland is not always based on facts (Lavikainen, 2010, Union of Students..., 2009; 2011). The marketing messages in the 
sample consistently gave either indications or direct promises of future employment prospects that are certainly beyond the HEIs to control. The Finnish HEIs could benefit from this study by taking a critical look at their own marketing differentiation activities. Instead of promising anything on the behalf of employers, HEIs could, as multiple examples in this study have shown, emphasise their own achievements by highlighting the development of teaching methods and the special characteristics of their learning communities.

\section{References}

Acevedo, A. (2011), "Business ethics 101: the student is not a customer", International Journal of Management Education, Vol. 9 No. 3, pp. 1-11.

Anctil, E.J. (2008), Selling higher education: marketing and advertising America's colleges and universities, Jossey-Bass, San Francisco.

Arambewela, R. (2010), "Student experience in the globalized higher education market: challenges and research imperatives" in Maringe, F. and Foskett, N. (Eds.), Globalization and internationalization in higher education: theoretical, strategic and management perspectives, Continuum, London, pp. 155-173.

Askehave, I. (2007), "The impact of marketization on higher education genres - the international student prospectus as a case in point", Discourse Studies, Vol. 9 No. 6, pp. 723-742.

Bishop, S.C. (2013), "The rhetoric of study abroad: perpetuating expectations and results through technological enframing", Journal of Studies in International Education, DOI $10.1177 / 1028315312472983$.

Cai, Y. and Kivistö, J. (2013), "Tuition fees for international students in Finland: where to go from here?", Journal for Studies in International Education, Vol. 17 No. 1, pp. $55-78$.

Capraro, A.J., Patrick, M.L. and Wilson, M. (2004), "Attracting college candidates: the impact of perceived social life", Journal of Marketing for Higher Education, Vol. 14 No. 1, pp. 93-105.

Cohen, A., Yemini, M. and Sadeh, E. (2013), "Web-based analysis of internationalization in Israeli teaching colleges", Journal of Studies in International Education, DOI: $10.1177 / 1028315313479131$.

Durkin, M., McKenna, S. and Cummins, D. (2012), "Emotional connections in higher education marketing", International Journal of Educational Management, Vol. 26 No. 2, pp. 153-161. 
Eriksson, P. and Kovalainen, A. (2008). Qualitative Methods in Business Research. Sage, Thousand Oaks.

Finnish Ministry of Education (2009), Korkeakoulujen kansainvälistymisstrategia 20092015, [Internationalisation strategy for higher education 2009-2015] Ministry of Education, Helsinki, available at:

http://www.minedu.fi/OPM/Julkaisut/2009/Korkeakoulujen_kansainvalistymisstrate gia_2009_2015.html (accessed 21 October, 2013).

Gibbs, P. (2008), "Marketers and educationalists - two communities divided by time?", International Journal of Educational Management, Vol. 22 No. 3, pp. 269-278.

Gomes, L. and Murphy, J. (2003), "An exploratory study of marketing international education online", International Journal of Educational Management, Vol. 17 No. 3, pp. 116-125.

Grebennikov, L. and Shah, M. (2013), "Monitoring trends in student satisfaction", Tertiary Education and Management, Vol. 19 No. 4, pp. 301-322.

Hayes, T. J. (2009), Marketing colleges and universities: A services approach. Washington Council for Advancement and Support for Education, Washington.

Hemsley-Brown, J. (2011), "Market heal thyself: the challenges of a free market in higher education", Journal of Marketing for Higher Education, Vol. 21 No. 2, pp. 115-132.

Hemsley-Brown, J. (2012), ""The Best Education in the World": Reality, Repetition or Cliche? International Students' Reasons for Choosing an English University", Studies in Higher Education, Vol. 3 No. 8, pp. 1005-1022.

Hemsley-Brown, J. and Oplatka, I. (2006), "Universities in a competitive global marketplace: A systematic review of the literature on higher education marketing", International Journal of Public Sector Management, Vol. 19 No. 4, pp. 316-338.

Ivy, J. (2008), "A new higher education marketing mix: the 7Ps for MBA marketing", International Journal of Educational Management, Vol. 22 No. 4, pp. 288-299.

Jacob, B., McCall, B.and Stange, K.M. (2013), "College as country club. Do colleges cater to students' preferences for consumption", NBER Working Paper No. 18745, National Bureau of Economic Research, Cambridge.

Lavikainen, E. (2010), Opiskelijan ammattikorkeakoulu 2010. Tutkimus ammattikorkeakouluopiskelijoiden koulutuspoluista, koulutuksen laadusta ja opiskelijakyvystä. [Student's UAS 2010. A study on study paths of UAS students, quality of education and study competences], Opiskelijajärjestöjen tutkimussäätiö, Helsinki.

Maassen, P., Kallioinen, O., Keränen, P., Penttinen, M., Spaapen, J., Widenhofer, R., Kajaste, M. and Mattila, J. (2012), From the bottom up: Evaluation of RDI activities of Finnish Universities of Applied Sciences, Finnish Higher Education Evaluation Council, Helsinki. 
Molesworth, M., Nixon, E. and Scullion, R. (2009), "Having, being and higher education: the marketisation of the university and the transformation of the student into consumer", Teaching in Higher Education, Vol. 14 No. 3, pp. 277-287.

Moogan, Y.J. (2011), "Can a higher education institution's marketing strategy improve the student-institution match?", International Journal of Educational Management, Vol. 25 No. 6, pp. 570-589.

Mulnix, M.W., Cojanu, K. and Pettine, S.B. (2011), "Critical role of the dominant coalition in higher education marketing strategy formulation", Research in Higher Education Journal, Vol. 11, pp. 1-10. Available at: http://www.aabri.com/manuscripts/11784.pdf (accessed 21 October, 2013).

Naidoo, R. and Jamieson, I. (2005), "Empowering participants or corroding learning? Toward a research agenda on the impact of student consumerism in higher education", Journal of Education Policy, Vol. 20 No. 3, pp. 267-281.

Newman, S. and Jahdi, K. (2009), "Marketisation of Education: Marketing, Rhetoric and Reality", Journal of Further and Higher Education, Vol. 33 No. 1, pp. 1-11.

Ooi, T.C., Ho, H. and Amri, S. (2010), "Education websites and their benefits to potential international students: a case study of higher education service providers in Malaysia", Current Issues in Education, Vol. 13 No. 1. Available at: http://cie.asu.edu/ojs/index.php/cieatasu/article/view/276 (accessed 21 October, 2013).

Pyykkö, R., Holm, K., Innola, M., Kallunki, J., Ketolainen, J., Lahtinen, M., Raevaara, M.,Savola, P.; Tujula, M., Vuorinen, B. and Björn, N. (2012), Korkeakoulujen lukukausimaksukokeilun seuranta ja arviointi. Työryhmän väliraportti 2. [Follow-up and evaluation of tuition fee trial at higher education institutions. Interim report 2 of the working group]. Available at: http://www.minedu.fi/OPM/Koulutus/artikkelit/lukukausimaksukokeilu/ (accessed 21 October, 2013).

Pyykkö, R., Holm, K., Innola, M., Kallunki, J., Ketolainen, J., Lahtinen, M., Raevaara, M.,Savola, P., Vuorinen, B. and Björn, N. (2013), Korkeakoulujen lukukausimaksukokeilun seuranta ja arviointi. Työryhmän väliraportti 3. [Follow-up and evaluation of tuition fee trial at higher education institutions. Interim report 3 of the working group] Available at: http://www.minedu.fi/OPM/Koulutus/artikkelit/lukukausimaksukokeilu/ (accessed 21 October, 2013).

Ramachandran, N.T. (2010), "Marketing framework in higher education", The International Journal of Educational Management, Vol. 24 No. 6, pp. 544-556.

Ross, M., Grace, D. and Shao, W. (2013), "Come on higher ed...get with the programme! A study of market orientation in international student recruitment. Educational Review, Vol. 65 No. 2, pp. 219-240.

Saarinen, T. and Nikula, T. (2013), "Implicit Policy, Invisible Language: Policies and 
Practices of International Degree Programmes in Finnish Higher Education" in Doiz, A., Lasagabaster, D. and Sierra, J.M. (Eds.), English-Medium Instruction at Universities: Global Challenges, Multilingual Matters, Bristol, pp. 131-150.

Stachowski, C.A. (2011), "Educational Marketing: A Review and Implications for Supporting Practice in Tertiary Education", Educational Management Administration \& Leadership, Vol. 39 No. 2, pp. 186-204.

Svensson, G. and Wood, G. (2007), "Are university students really customers? When illusion may lead to delusion of all!", International Journal of Educational Management, Vol. 21 No. 1, pp. 17-28.

Symes, C. (1996), Selling Futures: A New Image for Australian Universities? Studies in Higher Education, vol. 21 No. 2, 133-147.

Union of Students in Finnish Universities of Applied Sciences (2009), "Kannanotto 15.4.2009" [Statement], available at: http://samok.fi/2009/04/15/korkeakoulujenmarkkinoiden-on-perustuttava-tosiasioihin/ / (accessed 21 October, 2013).

Union of Students in Finnish Universities of Applied Sciences (2011), Kannanotto 07.03.2011" "[Statement] available at: http://samok.fi/2011/03/07/korkeakoulujenhakumainonta-faktatietoon-pohjautuvaksi/ (accessed 21 October, 2013).

Välimaa, J., Fonteyn, K., Garam, I., van den Heuvel, E., Linza, C., Söderqvist, M., Wolff, J., U. and Kolhinen, J. (2013), An evaluation of international degree programmes in Finland, Finnish Higher Education Evaluation Council, Helsinki.

van Rooij, S.W. and Lemp, L.K. (2010), "Positioning e-learning graduate certificate programs: niche marketing in higher education", Services Marketing Quarterly, vol. 31, no. 3, pp. 296-319.

Vauterin, J.J., Linnanen, L. and Marttila, E. (2011), "Customer orientation in higher education: the missing link in international student recruitment? A relationship marketing approach", Industry and Higher Education, vol. 25, no. 2, pp. 77-91.

Vuori, J. (2013), Are students customers in Finnish higher education? Tertiary Education and Management, vol 19, no. 2, pp.176-187.

Wilkins, S., Balakrishnan, M.S. and Huisman, J. (2012), "Student choice in higher education: motivations for choosing to study at an international branch campus", Journal of Studies in International Education, vol. 16, no. 5, pp. 413-433.

Williams, J. (2013), Consuming higher education: why learning can't be bought, Bloomsbury, London.

Wright, R.E. (2012), "Marketing orientations and higher education: applications and implications", The Journal of Applied Business and Economics, vol. 13, no. 5, pp. 53-57. 
Appendix 1.

List of documents: (accessed 11-22 March 2013)

\begin{tabular}{|c|c|c|}
\hline $\begin{array}{l}\text { Higher education } \\
\text { institution }\end{array}$ & $\begin{array}{l}\text { Bachelor programmes: } \\
\text { Degree Programme in ... }\end{array}$ & $\begin{array}{l}\text { Master programmes: } \\
\text { Degree Programme in... /Master's } \\
\text { Degree Programme in... }\end{array}$ \\
\hline Aalto University & - International Business & $\begin{array}{l}\text { - Engineering Physics and } \\
\text { Mathematics } \\
\text { - Accounting } \\
\end{array}$ \\
\hline Arcada UAS & $\begin{array}{l}\text { - International Business } \\
\text { Plastics Technology }\end{array}$ & $\begin{array}{ll}\text { International Business } \\
\text { Management }\end{array}$ \\
\hline Centria UAS & $\begin{array}{ll}\text { - } & \text { Business Management } \\
\text { - } & \text { Industrial Management } \\
\end{array}$ & \\
\hline Haaga-Helia UAS & - International Business & $\begin{array}{l}\text { - International Business } \\
\text { Management* }\end{array}$ \\
\hline $\begin{array}{l}\text { Hanken School of } \\
\text { Economics }\end{array}$ & & - Corporate Governance \\
\hline Hämeenlinna UAS & $\begin{array}{ll}- & \text { Automation } \\
& \text { Engineering } \\
\text { - } & \text { International Business } \\
\end{array}$ & $\begin{array}{l}\text { - Business Management and } \\
\text { Entrepreneurship }\end{array}$ \\
\hline Jyväskylä UAS & $\begin{array}{l}\text { - Logistics Engineering } \\
\text { - International Business }\end{array}$ & $\begin{array}{l}\text { Information Technology* } \\
\text { - International Business } \\
\text { Management* }\end{array}$ \\
\hline Kajaani UAS & - International Business & \\
\hline Karelia UAS & - International Business & \\
\hline Kemi-Tornio UAS & $\begin{array}{l}\text { - Business Information } \\
\text { Technology }\end{array}$ & \\
\hline Kymenlaakso UAS & - International Business & $\begin{array}{l}\text { International Business } \\
\text { Management* }\end{array}$ \\
\hline Lahti UAS & - International Business & $\begin{array}{l}\text { - International Business } \\
\text { Management }\end{array}$ \\
\hline $\begin{array}{l}\text { Lappeenranta } \\
\text { University of } \\
\text { Technology }\end{array}$ & & $\begin{array}{l}\text { - International Marketing } \\
\text { Management* } \\
\text { - Chemical and Process } \\
\text { Engineering* }\end{array}$ \\
\hline Laurea UAS & - Business Management & - Service Innovation and Design* \\
\hline Metropolia UAS & - Business and Logistics & - Business Informatics \\
\hline
\end{tabular}




\begin{tabular}{|c|c|c|}
\hline & - Civil Engineering & - Industrial Management \\
\hline Mikkeli UAS & $\begin{array}{ll}\text { - } & \text { Business Management } \\
\text { - Environmental } \\
\text { Engineering }\end{array}$ & \\
\hline Novia UAS & $\begin{array}{ll}\text { Environmental } \\
\text { Engineering }\end{array}$ & \\
\hline Oulu UAS & $\begin{array}{ll}\text { - } & \text { Business Information } \\
\text { Technology } \\
\text { - Information Technology }\end{array}$ & - Industrial Management \\
\hline Rovaniemi UAS & $\begin{array}{ll}\text { - } & \text { Innovative Business } \\
\text { Services } \\
\text { - } \\
\text { Information Technology }\end{array}$ & \\
\hline Saimaa UAS & $\begin{array}{l}\text { - International Business } \\
\text { - Mechanical Engineering } \\
\text { and Production } \\
\text { Technology } \\
\end{array}$ & $\begin{array}{l}\text { - International Business } \\
\text { Management }\end{array}$ \\
\hline Satakunta UAS & $\begin{array}{ll}\text { - } & \text { Environmental } \\
\text { Engineering } \\
\text { - } \\
\text { International Business } \\
\text { and Marketing Logistics }\end{array}$ & $\begin{array}{l}\text { - Business Management and } \\
\text { Entrepreneurship }\end{array}$ \\
\hline Savonia UAS & $\begin{array}{l}\text { - Industrial Management } \\
\text { - International Business }\end{array}$ & - Industrial Management* \\
\hline Seinäjoki UAS & - International Business & \\
\hline $\begin{array}{l}\text { Tampere University } \\
\text { of Technology }\end{array}$ & & - Business and Technology \\
\hline Tampere UAS & $\begin{array}{ll}\text { - } & \text { Environmental } \\
\text { Engineering } \\
\text { - } & \text { International Business } \\
\end{array}$ & - DP in Information Technology* \\
\hline Turku UAS & $\begin{array}{l}\text { - International Business } \\
\text { - Information Technology }\end{array}$ & $\begin{array}{l}\text { - International Business } \\
\text { Management* }\end{array}$ \\
\hline $\begin{array}{l}\text { University of } \\
\text { Eastern Finland }\end{array}$ & & - Service Management \\
\hline $\begin{array}{l}\text { University of } \\
\text { Jyväskylä }\end{array}$ & & $\begin{array}{l}\text { - Corporate Environmental } \\
\text { Management }\end{array}$ \\
\hline University of Oulu & & $\begin{array}{ll}\text { - } & \text { Finance } \\
\text { - } & \text { Computer Vision and Signal } \\
& \text { Processing }\end{array}$ \\
\hline University of Turku & & - $\quad$ Futures Studies \\
\hline University of Vaasa & & $\begin{array}{ll}\text { - } & \text { Finance } \\
\text { - Telecommunication } \\
\text { Engineering }\end{array}$ \\
\hline
\end{tabular}




\begin{tabular}{|l|l|l|}
\hline Vaasa UAS & $\bullet \begin{array}{l}\text { International Business } \\
\text { Anformation Technology }\end{array}$ & \\
\hline $\begin{array}{l}\text { Abo Akademi } \\
\text { Universitiy }\end{array}$ & & \\
\hline
\end{tabular}

*charging tuition fees 